\title{
Celebrating the Mayflower: 400 years of Anglo-American relations
}

\author{
Robert M. Hendershot ${ }^{1} \cdot$ Steve $^{\text {Marsh }}{ }^{2}$
}

Published online: 21 September 2020

(c) The Editor of the Journal 2020

It is a fitting tribute to the strength, vitality, contradictions and controversies of Anglo-American relations that their 400-year span can this year be bookended on one side by the Mayflower pilgrimage and, on the other, BREXIT and the closure of US President Donald Trump's (first?) administration. Trump has periodically been as popular and politically toxic in Britain as was King George III to the Founders of the American Republic. At the same time BREXIT reflects a continuing British reflexive Atlanticism and, reciprocally, unparalleled American fascination with the British Royal family suggests an ongoing popular interest in the 'motherland'. Indeed, the marriage of Prince Harry to biracial American divorcee Meghan Markle constitutes a thoroughly modern twist upon the familial hands across the water imagery invoked often by Winston Churchill through his Anglo-American parentage.

One of the most remarkable features within this tale of two nations is how their relationship has transitioned many times over through what in retrospect appears to be a continual bilateral dialogue spanning politics, culture, economics, identity, law, philosophy and so on. In the same way that the 'othering' of Britain was a key component of early American identity construction, so recognition of a shared AngloSaxonism was a central plank in the later Great Rapprochement. ${ }^{1}$ That British and American elites have so often found their interpretations of world events more alike than with any other country owes much to what Dobson has claimed to be a distinctive Anglo-American political tradition rooted in their interpretation and practice of

\footnotetext{
1 Bradford Perkins, The Great Rapprochement: England and the United States, 1895-1914 (New York: Atheneum, 1968); Srdjan Vucetic, The Anglosphere: A Genealogy of a Racialized Identity in International Relations (Stanford, CA: Stanford University Press, 2011).
}

Robert M. Hendershot

rhenders@grcc.edu

Steve Marsh

marshsi@cardiff.ac.uk

1 Grand Rapids, USA

2 Cardiff, UK 
Liberalism. ${ }^{2}$ And from this have flowed notions of a shared way of life, the defence of which has brought Britain and the US shoulder to shoulder in combat many times over and which helps explain the remarkably peaceful transition of global power from the British Empire to Pax Americana. ${ }^{3}$

George Bernard Shaw's quip that 'England and America are two countries separated by a common language' is often quoted by Anglo-American officials in emphasis of the opposite. More aptly, German Chancellor Bismarck prophetically noted that the US sharing of the English language would be the defining factor of the Twentieth century. He was correct, albeit his prophesy has stretched also into the twenty-first century. The British and American peoples are amongst the world's leading monoglots. Without the shared inheritance of the English language neither the extensive transatlantic dialogue referenced above, nor the popular sense of mutual affinity, would have been possible. Political elites have often emphasised the advantage of their shared language and history for their conduct and practice of diplomacy. For instance, describing his bilateral summit talks with President Ford in January 1975 as 'very, very relaxed' and 'free flowing', British Prime Minister Wilson elaborated: 'We don't have, you know, to spend about fifty minutes in every hour arguing about first principles, arguing about trying to convince one another. They are thoroughly practical and that's why you get six times as much results out of an hour of discussions such of the kind we've had. ${ }^{4}$ Even more importantly, the medium of English has facilitated an interchange of not just politics but also ideas, art, music, protest, literature and so forth at all levels of Anglo-American society. And the pace, reach and unregulated nature of this exchange is continuing to increase and expand as the communications revolution compresses the time and space of geographical separation between Britain and the US. Americans may not yet have embraced the peculiarities of cricket, but 'soccer' has now taken root in the US and American football has a loyal and growing following in the UK.

Implicit in all of this, of course, is the idea that the relationship between the UK and the US is unique, different somehow in quality and, historically at least, importance. Over time this notion has so engaged, intrigued, frustrated and in some cases simply annoyed a host of scholars that a rich and still growing literature has evolved in an attempt to address it. Part of the challenge therein has been in ascertaining what it is that (allegedly) makes Anglo-American relations special. Here there are a wide variety of views. In the same vein that Churchill conjured the special relationship in his famous Fulton speech in 1946 as comprising a compelling blend of interest and sentiment, so some scholars see a 'natural relationship' between the UK and US. ${ }^{5}$ This was born of shared values, culture, democratic principles, and kinship

\footnotetext{
${ }^{2}$ Alan P Dobson, 'Anglo-American Political Culture,' in Culture Matters: Anglo-American Relations and the Intangibles of 'Specialness', eds. Robert M Hendershot and Steve Marsh (Manchester: Manchester University Press, 2020), 108-29; Alan P Dobson and Steve Marsh eds., Anglo-American relations and the transmission of ideas: A shared political tradition? (New York: Berghahn, forthcoming).

${ }^{3}$ For an interesting discussion of succession see Stephen R. Rock, Why Peace Breaks Out: Great Power Rapprochement in Historical Perspective (Chapel Hill: University of North Carolina Press, 1989).

${ }^{4}$ Bodleian Library, MS Wilson, 1263, Transcript of Prime Minister's Q \& A session at the National Press Club Luncheon, 31 January 1975.

${ }^{5}$ For a thought-provoking book on the importance of Churchill and the Fulton speech to UK-US relations see Alan P Dobson and Steve Marsh eds., Churchill and the Anglo-American Special Relationship (London: Routledge, 2017).
} 
and evolved such that it became manifest in habits of cooperation and shared attitudes about how to deal with international issues. ${ }^{6}$ Others, however, see it as an artefact; Reynolds cast it as a British diplomatic device to help manage Britain's relative decline and Gamble as a psychological crutch to cushion the blow of power lost. ${ }^{7}$ For still others there is no such thing as a special relationship and it is a travesty to dress-up Anglo-American relations in such a 'myth'. ${ }^{8}$ And yet others argue that even if it were a myth, this exerted influence upon the conduct of Anglo-American relations that needs to be taken into account when explaining decisions and behaviour. ${ }^{9}$

Questions of purpose and approach complicate further within this scholarship the quest to reconcile different views and/or to resolve upon one as being the most credible. Some works are more concerned with advocacy than explanation, or what has been labelled the practical rather than the scientific and the contemplative attitudes towards the past. ${ }^{10}$ The former includes works preoccupied with the moving present that are either highly critical or strongly supportive of the Anglo-American relationship and want it abandoned, changed or nurtured consequently. Consider, for instance, those who believed the special relationship to be an impediment to Britain's European vocation or those who see it as the core of an emergent Anglosphere. ${ }^{11}$ Some of these works require critical reading to discern their real purpose for they often conflate what is with what should be in order to strengthen the persuasiveness of partisan arguments.

Neither is it straightforward when one considers explanation developed through scientific and contemplative attitudes towards the past. Perhaps the most obvious and important differences in approach towards the study of Anglo-American relations are those adopted by scholars in the fields of International Relations and Diplomatic

\footnotetext{
${ }^{6}$ Harry C Allen, Great Britain and the United States: A History of Anglo-American Relations 17831952 (London: Odhams Press, 1954); Henry Butterfield Ryan, The Vision of Anglo-America: The US-UK Alliance 1943-46 (Cambridge: Cambridge University Press, 1987).

7 David Reynolds, Britannia Overruled. British Policy and World Power in the Twentieth Century (London: Longman, 2014); Andrew Gamble, Britain in Decline (London: Macmillan, 1994).

8 Edward Ingram, 'The Wonderland of the Political Scientist', International Security 22, (1997): 53-63; Max Beloff, 'The Special Relationship: An Anglo-American Myth', in A Century of Conflict: Essays for A.J.P. Taylor, ed. Martin Gilbert (London: Hamish Hamilton, 1966), 151-171.

9 Steve Marsh, 'Anglo-American relations and the past present: insights into an (ongoing) mythologisation of a special relationship', Journal of Transatlantic Studies 17 (2019): 310-40; Steve Marsh, "Global Security: US-UK relations": lessons for the special relationship?,' Journal of Transatlantic Studies 10, (2012); 182-99; Robert M Hendershot, 'Affection is the Cement that Binds Us', in Anglo-American relations: Contemporary Perspectives, eds. Alan P Dobson and Steve Marsh (London: Routledge, 2013), 52-81; Robert M Hendershot, Family Spats: Perception, Illusion and Sentimentality in the Anglo-American Special Relationship (Dortmund: Verlag, 2008).

10 Michael Oakeshott, 'The Activity of Being An Historian', in Rationalism in Politics and Other Essays (London: Methuen, 1962), 137-168.

11 William Wallace, 'The collapse of British foreign policy', International Affairs 81 (2005): 53-68; Tim Oliver and William Wallace, 'A bridge too far: the United Kingdom and the transatlantic relationship' in The Atlantic alliance under stress: US-European relations after Iraq, ed. David Andrews (Cambridge: Cambridge University Press, 2005), 152-76; James C Bennett, The Anglosphere Challenge: Why the English-Speaking Nations Will Lead the Way in the Twenty-First Century (New York: Rowman and Littlefield, 2004); Douglas Stuart, 'NATO's Anglosphere Option: Closing the Distance between Mars and Venus', International Journal 60, (Winter, 2004/2005): 171-187; Lawrence M. Mead, 'Why Anglos Lead', The National Interest 82, (2005/06): 1-8.
} 
History. As Elman and Elman note, there are enduring epistemological and methodological divides between these fields and what they seek to achieve is different: 'Political scientists are more likely to look to the past as a way of supporting or discrediting theoretical hypothesis, while historians are more likely to be interested in past international events for their own sake. ${ }^{12}$ The contribution to meaning and understanding made by each of these approaches, characterised by Hollis and Smith as a dichotomy between the 'inside' and the 'outside' aspect of events, is often fiercely contested. For instance, Hollis and Smith argue that the former makes sense of the past by providing meaning but not explanation. Reynolds disagrees. He contends that the 'inside' approach provides explanation through 'the understanding, reasoning and perceptions of the actors and not in any pattern, theoretical or colligatory, superimposed on action and events by "observers" or "narrators"., 13

Once these debates are applied to the study of Anglo-American relations it becomes quickly apparent that even when scholars in International Relations and Diplomatic History ask the same question, the answers will be different. ${ }^{14}$ For instance, political scientists seek to determine what in general constitutes a special relationship within international relations. This leads them to develop criteria by which to judge Anglo-American and other relationships, sometimes on a comparative basis. ${ }^{15}$ Historians, though, determine by policy tracing through primary source materials Anglo-American modes of behaviour. A special relationship is thereby identified where the conduct of Anglo-American affairs differs from those that might normally be expected in the conduct of international relations. It is for this reason, for instance, that one finds repeated emphasis in the literature upon nuclear weapons technology sharing as exemplifying unusually close UK-US relations.

This traditional 'dialogue of the deaf' between the fields of International Relations and Diplomatic History, coupled with 'practical' texts, helps to explain the volume of, and contradictory conclusions within, the literature on UK-US relations. Mining down into coverage by Diplomatic Historians, one also finds many differences of interpretation but-in broad-brush terms-something, too, of a consensus that most important to Anglo-American relations is a functionalist dynamic

\footnotetext{
${ }^{12}$ Colin Elman and Miriam Fendius Elman, 'Introduction: Negotiating International History and Politics,' in Bridges and Boundaries, eds. Colin Elman and Miriam Fendius Elman (Cambridge, MA: MIT Press, 2001), 35.

${ }^{13}$ Charles Reynolds, 'Explaining the Cold War' in Deconstructing and Reconstructing the Cold War, eds. Alan P. Dobson, Shahin Malik and Graham Evans (Aldershot: Ashgate, 1999), 63-64; Martin Hollis and Steve Smith, Explaining and Understanding International Relations (Oxford: Clarendon Press, 1991), 3. Charles Reynolds, Theory and Explanation in International Politics (London: Martin Robertson, 1973); Ian Lustick, 'History, Historiography and Political Science', American Political Science Review 90, (1996): 605-618; George Lawson, 'The Eternal Divide? History and International Relations', European Journal of International Relations 18, (2012): 203-226; Colin Elman and Miriam Elman, Diplomatic History and International Relations Theory: Respecting Difference and Crossing Boundaries (London: Sage, 2004).

${ }^{14}$ See 'Introduction' in Anglo-American Relations: Contemporary Perspectives, eds Dobson and Marsh.

15 Alex Danchev, On Specialness: Essays in Anglo-American Relations (London: Macmillan, 1998); John Dumbrell and Alex Schafer eds., America's 'Special Relationships': Foreign and Domestic Aspects of the Politics of Alliance (London: Routledge, 2009).
} 
that warrants each party treating the other in ways more preferential than they do their other alliances and friendships. This emphasis flows from a predilection within Diplomatic History for explanatory factors of behaviour that are somehow tangible or quantifiable. It also flows from a dominance of (neo)-realist assumptions therein about humankind and the international system in which the UK and US have conducted their relations. Put crudely, humankind has a capacity for violence and is inherently flawed. In the absence of a Leviathan to regulate the conduct of states in their international relationships, so states are locked into a Hobbesian world wherein alliances are determined above all else by calculations of mutual utility. This predominance within the literature of functionalist calculation is naturally reinforced for Diplomatic Historians, too, by their reliance upon primary sources that are provided by the men and women charged with defending the national interest in this anarchic international system in ways that best provided for the nation's security and prosperity. This did not proscribe for these people intangibles such as morality from impacting their policies but it is often assumed to have pushed these considerations to the margins of influence.

It is perhaps to be expected, therefore, that the bulk of the extant literature evinces the idea-explicitly or implicitly-that the Anglo-American relationship developed from shared and overlapping national interests such that a bond of mutual utility was formed and subsequently maintained. ${ }^{16}$ And it is for this reason that one encounters numerous accounts of Anglo-American relations that focus on one or more aspects of this functional dynamic, including defence, nuclear and intelligence cooperation and entwined economies. ${ }^{17}$ Moreover, the logic of this conceptualisation of Anglo-American relations is responsible for two of the mainstream narratives within accounts of them. The first of these is the narrative of decline which developed as British relative capabilities atrophied from the zenith of US-UK cooperation in WW2 to a point where presently the Anglo-American relationship is profoundly asymmetric. ${ }^{18}$ The second narrative is that even if one accepts a temporal claim to a special relationship, this situation will only continue while common interests abide and each side can be of persuasive importance to the other. At some point, therefore, power and interests will inevitably so shift within Anglo-American relations that one, or both, parties will conclude there is no longer a persuasive reason to accord the other a privileged position within their international relationships. The

\footnotetext{
16 This is not to say the field is bereft of different emphases. See, for instance, Sam Edwards, Allies in Memory, (Cambridge: Cambridge University Press, 2015); Hendershot, Family Spats; selected chapters in Anglo-American Relations: Contemporary Perspectives, eds Dobson and Marsh.

17 For instance, Alan P Dobson, The Politics of the Anglo-American Economic Special Relationship (Sussex and New York: Wheatsheaf and St. Martin's Press, 1988); John Baylis, Anglo-American Defence Relations 1939-1984: The Special Relationship (London: Macmillan 1984); John T. Richelson and Desmond Ball, The Ties that Bind: Intelligence Cooperation Between the UKUSA Countries (Hemel Hempstead: Allen and Unwin, 1985).

18 Donald C. Watt, Succeeding John Bull: America in Britain's Place 1900-1977 (Cambridge: Cambridge University Press, 1984); Ritchie Ovendale, Anglo-American relations in the Twentieth Century (Basingstoke, Macmillan, 1998); Randall Bennett Woods, A Changing of the Guard: Anglo-American Relations, 1941-1946 (Chapple Hill: University of North Carolina Press, 2008); David Reynolds, Britannia Overruled.
} 
logic inherent in this narrative is that it is not a case of will Anglo-American relations cease to be special—assuming one accepts that ever they were-but when. ${ }^{19}$

For some this transition from 'special' to 'normal' Anglo-American relations would owe primarily to British relative decline. For others the reason would be systemic change - the end of the Cold War, for example, removing the necessity of close relations between Britain and the US. For still others, increasingly divergent strategic interests would pull the erstwhile partners apart and reduce the quantity and quality of interaction opportunities that were so important to the relationship's unique status. Whatever the case, though, scholars, practitioners and journalists have been prompted periodically to declare, or predict, the end of the special relationship. As far back as 1967 Thomas L. Hughes of the State Department's Intelligence and Research Bureau wryly observed that: 'The special relationship has been pronounced dead as often as Martin Bormann has been reported alive. Indeed, perhaps the best evidence that it is still alive is the fact that its detractors feel obliged to reannounce its death every few months. ${ }^{20}$

As Britons and Americans celebrate in 2020400 years of what Churchill termed 'fraternal association', it is evident that political scientists and historians alike continue to struggle with the concept of the special relationship, the impact of the special relationship on the conduct of Anglo-American relations and, perhaps especially, why the special relationship refuses to die to time. After all, the gap between the prevailing narrative of a unique partnership of 'equals' and the reality of AngloAmerican relations is not only now wide but it is also sometimes exposed as being embarrassingly so. Indeed, a House of Commons Foreign Select Committee felt compelled to recommend in 2010 that the term special relationship no longer be used to describe the totality of UK-US relations for it was 'misleading'. 21

It is for these reasons that this special edition marks the 400th anniversary of the Mayflower voyage by focusing not on the special relationship per se but instead upon the scholarship about it. This is not in any way to diminish the often excellent and insightful body of literature that has engaged, in its different ways, the special relationship to date. However, it is not unreasonable to ask whether this scholarship has evolved as far as has the subject matter it studies? Are scholars asking all of the necessary questions? Are they availing themselves of all the available avenues of investigation? And are they adapting satisfactorily to new technologies and the implications of information storage in the digital age? In what follows we acknowledge that traditional modes of investigation can still offer much in terms of new insights into and understanding of Anglo-American relations and the special relationship. However, we also suggest that the field has been slow to adapt to the added

\footnotetext{
19 John Dickie, Special No More: Anglo-American Relations: Rhetoric and Reality (London: Weidenfeld \& Nicolson, 1994).

20 Jonathan Colman, 'Communication: "What Now for Britain?" The State Department's Intelligence Assessment of the "Special Relationship," 7 February 1968', Diplomacy and Statecraft 19 (2008), 350360 .

21 House of Commons Foreign Affairs Committee (HCFAC), 'Global Security: US: UK Relations', HC 114, Incorporating HC 1100-i, Session 2008-2009, (London: The Stationery Office Limited, 2010), pt4: 3.
} 
value that can be provided by new lines of enquiry and, especially, the opportunities afforded by interdisciplinary research.

Consequently, Alan Dobson's contribution grounds this special edition by assessing in detail how the study of Anglo-American relations has progressed over the past 50 years. In this he shows us how the field has grown increasingly diverse as well as been marked by widely varying assessments of the value and influence of Anglo-American relations. Identifying themes of change and continuity in scholarship since the 1970s, Dobson maps evolving appraisals of the special relationship's existence (or otherwise), explains important consequences of the field's traditional focus on high politics, including diplomacy, defence, and security, and highlights several new approaches likely to impact the field of debate in the years ahead. We should also acknowledge that this article marks a break in his long-running policy of not publishing his own work in the journal that he created nearly two decades ago. Yet we are grateful that he has made an exception in this case, for we could think of no one better positioned to offer a historiographic retrospective that will be useful to experienced scholars and new graduate students alike.

Clive Webb's article continues the theme of historiographical reflection and focuses on how issues of race and ethnicity have been comparatively understudied in the field of Anglo-American relations. He points out that to some extent this marginalisation reflects a broader trend in foreign policy scholarship, and that this is particularly unfortunate for our field because concepts of race and ethnicity have long been of material importance as sources of cooperation and conflict between the US and the UK. However, his article also demonstrates how the tides of scholarship have started to turn, and appraises important works which have begun to demonstrate the ability of race and ethnicity studies to illuminate key aspects of AngloAmerican relations. His article concludes with a necessary and timely call to action: the literature he surveys must be integrated into the broader narratives of our field, and he proposes specific aspects of race and ethnic relations that deserve further study in the years to come.

Robert Hendershot's essay offers parallel reflections on how the 'cultural turn' in diplomatic history has served to increasingly open up new analytical spaces in the study of both the overall historical relationship between Britain and America, which dates from the early 1600s onward, and the comparatively modern special relationship of the twentieth and twenty-first centuries. While Hendershot finds that the role of culture in post-1940 Anglo-American relations has been consistently underexplored in favour of more traditional methods of historical analysis, in recent years more and more specialists have engaged cultural issues-including but not limited to investigations of mentalities, gender, sexuality, ethnicity, nationalism, race, religion, and memory - in order to more fully understand the special relationship's complex operational dynamic. In surveying this important and growing field of study, Hendershot also identifies additional cultural questions and methodologies that deserve academic attention in the next century of Anglo-American relations.

David Ryan, for his part, takes us on a tour of collective memory theory and asks us to consider its implications for nation states and scholars alike. Focusing on the version of Winston Churchill that has been constructed in the cultural memory of the US, Ryan provides a case study of how perceptions of the past influence 
contemporary foreign policy tactics and decision-making. By demonstrating how various American leaders have rhetorically embraced a reductive but powerful version of Churchill, Munich, and the 'good war' mythology of World War Two, his article reveals how simplistic historical lessons drawn from collective memory have been harnessed by elites to exaggerate threats and manipulate public opinion, often with unfortunate consequences. While this article advances a significant thesis in its own right, it also serves as an exemplary tutorial in how memory theory may be applied to the study of Anglo-American and wider international relations.

Finally, in order to complement the diverse scholarly approaches covered in this special edition, we thought it would be novel and appropriate to include insights from an institution centrally involved in the recording, preservation and dissemination of materials critical to the study of Anglo-American relations. To that end we reached out to the Ronald Reagan Presidential Library and Museum in Simi Valley, California, and were delighted when Director Duke Blackwood and his staff took up the challenge. Registrar Jennifer Torres, et al., not only detail the textual, video, audio, and artefact materials in their collections pertinent to Anglo-American relations, but also explain the institution's evolving goals, processes, and challenges. The article engages the unique laws that govern federal records and their declassification in the US, particularly the Freedom of Information Act, relates how archival staff organise collections in light of both researcher interest and practical considerations, and elucidates the complexities facing the Library (and the archival profession at large) in their work to increase researcher access through digitisation. As the administration of archival collections and the condition of access to them will increasingly impact the work of academics in future, we are confident that readers of the JTS will find this article to be of keen interest and join us in thanking the Library staff for sharing their expertise.

\section{References}

Allen, Harry C. 1954. Great Britain and the United States: A History of Anglo-American Relations 17831952. London: Odhams Press.

Baylis, John. 1984. Anglo-American Defence Relations 1939-1984: The Special Relationship. London: Macmillan.

Beloff, Max. 1966. The Special Relationship: An Anglo-American Myth'. In A Century of Conflict: Essays for A.J.P. Taylor, ed. G. Martin, 151-171. London: Hamish Hamilton.

Bennett, James C. 2004. The Anglosphere Challenge: Why the English-Speaking Nations Will Lead the Way in the Twenty-First Century. New York: Rowman and Littlefield.

Colman, Jonathan. 2008. Communication: "What Now for Britain?" The State Department's Intelligence Assessment of the "Special Relationship", 7 February 1968. Diplomacy and Statecraft 19: 350-360.

Danchev, Alex. 1998. On Specialness: Essays in Anglo-American Relations. London: Macmillan.

Dickie, John. 1994. Special No More: Anglo-American Relations: Rhetoric and Reality. London: Weidenfeld \& Nicolson.

Dobson, Alan P. 1988. The Politics of the Anglo-American Economic Special Relationship. Sussex and New York: Wheatsheaf and St. Martin's Press. 
Dobson, Alan P. 2020. Anglo-American Political Culture. In Culture Matters: Anglo-American Relations and the Intangibles of 'Specialness, ed. Robert M. Hendershot and Steve Marsh, 108-129. Manchester: Manchester University Press.

Dobson, Alan P and Steve Marsh (eds). forthcoming. Anglo-American Relations and the Transmission of Ideas: A Shared Political Tradition? New York: Berghahn.

Dobson, Alan P and Steve Marsh (eds.). 2017. Churchill and the Anglo-American Special Relationship. London: Routledge.

Dumbrell, John and Alex Schafer (eds.). 2009. America's 'Special Relationships': Foreign and Domestic Aspects of the Politics of Alliance. London: Routledge.

Edwards, Sam. 2015. Allies in Memory. Cambridge: Cambridge University Press.

Elman, Colin, and Miriam Elman. 2004. Diplomatic History and International Relations Theory: Respecting Difference and Crossing Boundaries. London: Sage.

Elman, Colin and Fendius Elman Miriam (eds.). 2001. Bridges and Boundaries. Cambridge, MA: MIT Press.

Gamble, Andrew. 1994. Britain in Decline. London: Macmillan.

Hendershot, R.M. 2013. Affection is the Cement that Binds Us'. In Anglo-American Relations: Contemporary Perspectives, ed. A.P. Dobson and S. Marsh, 52-81. London: Routledge.

Hendershot, Robert M., and Family Spats. 2008. Perception, Illusion and Sentimentality in the AngloAmerican Special Relationship. Dortmund: Verlag.

Hollis, Martin, and Steve Smith. 1991. Explaining and Understanding International Relations. Oxford: Clarendon Press.

Ingram, Edward. 1997. The Wonderland of the Political Scientist. International Security 22: 53-63.

Lawson, George. 2012. The Eternal Divide? History and International Relations. European Journal of International Relations 18: 203-226.

Lustick, Ian. 1996. History, Historiography and Political Science. American Political Science Review 90: 605-618.

Marsh, Steve. 2012. "Global Security: US-UK relations”: Lessons for the Special Relationship? Journal of Transatlantic Studies 10: 182-199.

Marsh, Steve. 2019. Anglo-American Relations and the Past Present: Insights into an (Ongoing) Mythologisation of a Special Relationship. Journal of Transatlantic Studies 17: 310-340.

Mead, Lawrence M. (2005/06). Why Anglos Lead. The National Interest 82: 1-8.

Oakeshott, Michael. 1962. Rationalism in Politics and Other Essay. London: Methuen.

Oliver, Tim, and William Wallace. 2005. A Bridge Too Far: The United Kingdom and the Transatlantic Relationship. In The Atlantic Alliance Under Stress: US-European Relations After Iraq, ed. David Andrews, 152-176. Cambridge: Cambridge University Press.

Ovendale, Ritchie. 1998. Anglo-American Relations in the Twentieth Century. Basingstoke: Macmillan.

Perkins, Bradford. 1968. The Great Rapprochement: England and the United States, 1895-1914. New York: Atheneum.

Reynolds, Charles. 1973. Theory and Explanation in International Politics. London: Martin Robertson.

Reynolds, Charles. 1999. Explaining the Cold War. In Deconstructing and Reconstructing the Cold War, ed. Alan P. Dobson, Shahin Malik, and Graham Evans. Aldershot: Ashgate.

Reynolds, David. Britannia Overruled. British Policy and World Power in the Twentieth Century. London: Longman, 2014.

Richelson, John T., and Desmond Ball. 1985. The Ties that Bind: Intelligence Cooperation Between the UKUSA Countries. Hemel Hempstead: Allen and Unwin.

Rock, Stephen R., and Why Peace Breaks Out. 1989. Great Power Rapprochement in Historical Perspective. Chapel Hill: University of North Carolina Press.

Ryan, Henry Butterfield. 1987. The Vision of Anglo-America: The US-UK Alliance 1943-46. Cambridge: Cambridge University Press.

Stuart, Douglas. 'NATO's Anglosphere Option: Closing the Distance between Mars and Venus.' International Journal 60, (Winter, 2004/2005): 171-187.

Vucetic, Srdjan. 2011. The Anglosphere: A Genealogy of a Racialized Identity in International Relations. Stanford, CA: Stanford University Press.

Wallace, William. 2005. The Collapse of British Foreign Policy. International Affairs 81: 53-68.

Watt, Donald C. 1984. Succeeding John Bull: America in Britain's Place 1900-1977. Cambridge: Cambridge University Press.

Woods, Randall Bennett. 2008. A Changing of the Guard: Anglo-American Relations, 1941-1946. Chapel Hill: University of North Carolina Press. 
Publisher's Note Springer Nature remains neutral with regard to jurisdictional claims in published maps and institutional affiliations.

Robert M. Hendershot is Professor of History in the Department of Social Sciences at Grand Rapids Community College, USA. Specialising in the historical influence of culture, identity, public opinion, and collective memory upon Anglo-American relations, his works include Gerald Ford and Anglo-American Relations: Re-Valuing an Interim Presidency (co-authored with Steve Marsh and Tia Culley, University of Michigan Press, forthcoming), Culture Matters: Anglo-American Relations and the Intangibles of 'Specialness' (co-edited with Steve Marsh, Manchester University Press, 2020), and Family Spats: Perception, Illusion, and Sentimentality in the Anglo-American Special Relationship (VDM Verlag, 2008).

Steve Marsh is Reader in International Relations at Cardiff University, UK. His books include Churchill and the Anglo-American special relationship (Routledge, 2017) and Anglo-American Relations: Contemporary Perspectives (Routledge, 2013) (both co-edited with Alan Dobson), The European Union in European Security (co-authored with Wyn Rees, Routledge, 2012), US Foreign Policy Since 1945 (coauthored with Alan Dobson, 2nd edition, Routledge, 2006), International Relations of the European Union (co-authored with Hans Mackenstein, Pearson, 2006), and Anglo-American Relations and Cold War Oil (Palgrave, 2003). 